\title{
APPLICATION OF TISSUE CULTURE TECHNIQUES IN POTATO
}

\author{
APLICAÇÃO DA CULTURA DE TECIDOS VEGETAIS EM BATATA
}

\section{Tâmara Prado de MORAIS ${ }^{1}$; Simone Abreu ASMAR ${ }^{1}$; Herick Fernando de Jesus SILVA² José Magno Queiroz LUZ ${ }^{3}$; Berildo de MELO ${ }^{3}$}

1. PhD in Plant Science, Instituto de Ciências Agrárias - ICIAG, Universidade Federal de Uberlândia - UFU, Uberlândia, MG, Brazil. 2. Doctorate student in Plant Science, ICIAG - UFU. 3. Associate professor, ICIAG - UFU. jmagno@ufu.br

\begin{abstract}
Potato is the world's most important non-cereal food crop, and therefore, it is considered one of the major food sources for humankind. Its conventional propagation is asexual, by using the tuber, which allows the accumulation and dissemination of pathogens to new cultivation areas. This fact not only impairs the yield of this solanaceous plant, but also threatens the maintenance of genotypes for commercial or breeding purposes. Due to the impossibility of using botanical seed, conservation and exchange of germplasm of this species by means of conventional methods are not feasible. In all potato-producing regions, the demand for high-quality tubers has been paramount to ensure crops production. Thus, biotechnological techniques based on tissue culture are very important. Plant tissue culture offers alternative methods of propagation by in vitro techniques that provide production and multiplication of material with high sanity. Thus, this literature review summarizes the history and current situation of tissue culture techniques applied to potato crop. Besides clonal multiplication, this biotechnological tool makes available initial indexed material to breeding programs and certified seed potato, and facilitates the exchange and conservation of germplasm. For all these reasons, the use of these techniques in potato production chain directly benefits producers by providing high-quality propagules.
\end{abstract}

KEYWORDS: Solanum tuberosum L. In vitro cultivation. Seed potato. Pathogen elimination.

\section{INTRODUCTION}

Potato (Solanum tuberosum L.) is an annual solanaceous plant from the Andes (MENEZES et al., 1999). Its commercial product, the tuber, is the underground stem adapted to work as reserve source and reproduction mean (FORTES; PEREIRA, 2003b). It is a culture of outstanding importance worldwide for having socio-economic repercussions, and for being one of the major food sources for humankind. Potato is cultivated in about 150 countries (BASERA et al., 2018), and is the most important non-cereal food crop in the world (BAMBERG et al., 2016; NIKITIN et al., 2018). Last harvest season, Brazil produced 4.3 million tons of potato, in an area of 803,900 hectares (IBGE, 2017).

On a commercial scale, potato has vegetative propagation. However, this type of multiplication can accumulate several systemic fungi, bacteria and virus infections that provoke degeneration in the plants, culminating with yield and vigor losses (NIKITIN et al., 2018). Thus, the use of virus-free propagative material, with high phytosanitary, physiological and genetic quality is of great importance to ensure that the plant expresses its maximum yield potential.

In this scope, plant tissue culture can be applied to potato production chain in order to efficiently propagate the material of interest, maintain germplasm banks, facilitate genetic exchange, provide the study of this species and of its interactions with biotic and abiotic factors, and to produce genetically modified plants and pathogenfree seed potatoes. This literature review summarizes some relevant results obtained with tissue culture in potatoes from 1977 to 2018 . We apologize in advance for the papers not included in this review, due to the limited length of our manuscript, and encourage more publications on this subject to contribute to or innovate existing knowledge.

\section{TISSUE CULTURE IN POTATOES}

\section{Micropropagation \\ In vitro establishment}

Among plant tissue culture techniques, micropropagation has the greatest practical application (reviewed in SHAHZAD et al., 2017). Several studies have been reported in the literature, aiming at the optimization of potato micropropagation protocols (ÁVILA et al., 1994; PEREIRA; FORTES, 2000, 2004; DUTRA et al., 2010; VENKATASALAM et al., 2013). However, one of the greatest difficulties in the development of these protocols is the in vitro establishment of plants, mainly due to fungal, viral and bacterial contaminations.

Fungi and yeasts can be controlled by eliminating the contaminated material (LEIFERT; WOODWARD, 1998), or by previously sanitizing 
the explants. In this case, potato shoots are disinfested by immersion in $70 \%$ alcohol for 15 seconds, followed by immersion for 15 minutes in $1.5 \%$ sodium hypochlorite solution with $0.1 \%$ Tween-80, and rinsed three times with distilled and autoclaved water (PEREIRA; MATTOS; FORTES, 2003).

Viruses can be physically (heat) or chemically (by antiviral compounds) eliminated. In a study developed by Nascimento et al. (2003), potato microcuttings with positive reaction to Potato virus $\mathrm{Y}$ (PVY) were subjected to thermotherapy $\left(37^{\circ} \mathrm{C}\right)$ and chemotherapy [Ribavirin (RBV), 5Azacitidine (AZA) and 3-Deazauridine (DZD)]. The thermotherapy, during 30 and 40 days, eliminated 20 and $37.5 \%$ of PVY, respectively. Among the chemotherapeutic agents, RBV presented the best eradication rates, and obtained $55.5 \%$ of healthy plants. These authors also verified that simultaneous treatments of thermotherapy and chemotherapy showed higher efficiency in virus elimination, reaching percentages of $83.3,70.0$, and 50.0 of healthy plants, with RBV, AZA, and DZD, respectively.

For the control of bacterial contamination, the use of substances antagonistic to these microorganisms is required. The application of antibiotics in the decontamination process may be beneficial since bacteria compete with plants for the nutrients of the culture medium, and may excrete toxic substances to explants (SCHERWINSKIPEREIRA, 2010). Antibiotics may be incorporated into the culture medium or directly used on contaminated explants (SALEHI; KHOSH-KHUI, 1997). In potato tissue culture, Pereira, Mattos and Fortes (2003) reported that the antibiotics ampicillin, chloramphenicol, streptomycin and tetracycline in concentrations varying from 32 to $256 \mathrm{mg} \mathrm{L}^{-1}$ inhibited the growth of endophytic bacteria. Besides acting on microorganisms, these antibiotics can also affect explants survival. The addition of tetracycline and chloramphenicol to the culture medium adversely affects the in vitro development of potato explants; conversely, ampicillin has no phytotoxic effects on growth and multiplication rate, and may be indicated for in vitro decontamination of this species (PEREIRA; FORTES, 2003b).

In vitro established plant material is more readily used as an explant donor than field-grown material (as surface disinfestation treatments are no longer required), once the established material is carefully handled under aseptic conditions (FORTES; PEREIRA, 2001; PEREIRA; FORTES, 2003a, b, 2004a; GONÇALVES et al., 2009).

\section{Multiplication}

Several parts of the mother plant can be used as explant source at the multiplication stage. In vitro potato regeneration protocols have been reported using immature zygotic embryos (PRETOVA; DEDICOVA, 1992), stem segments (GARCÍA; MARTÍNEZ, 1995; SANTIAGO et al., 2012; KAUR; REDDY; KUMAR, 2017; ALI et al., 2018; SILVA FILHO et al., 2018), leaves (CEARLEY; BOLYARD, 1997; KAUR; REDDY; KUMAR, 2017), tuber discs (ESNA-ASHARI; VILLIERS, 1998), meristems (BADONI; CHAUHAN, 2009), and shoot tips (DUTRA et al., 2010).

Due to the high susceptibility of potato to diseases, especially to viruses, several studies have started micropropagation by using meristems and shoot tips as explants in order to produce virus-free seed potato. However, some aspects may compromise the success of this technique, such as the delay in the differentiation of the meristematic tissue in the culture medium, the possibility of contamination (FORTES; PEREIRA, 2003a; PEREIRA; MATTOS; FORTES, 2003), and explant survival difficulty due to its small size.

The relationship between explant size, survival rate and pathogen elimination were observed by El-Fiki et al. (1992). In this work, seven potato cultivars were evaluated to determine the ideal size of the shoot tip and the efficiency in PVX eradication (Potato virus $X$ ). Higher seedling survival and growth rates were obtained by using larger explants $(0.4 \mathrm{~mm})$, although they presented smaller percentage of healthy plants (21.2) when compared with the explants of $0.2 \mathrm{~mm}$ (47.4).

Despite the proven efficiency of meristem culture in pathogens eradication, the combination of this technique with antiviral treatments to ensure pathogen elimination is often necessary. Wang et al. (2006) reported higher frequency in the regeneration of PLRV-free (Potato leafroll virus) and PVY-free (90 and 93\%, respectively) potato seedlings by applying thermotherapy, followed by meristem culture. The in vitro technique itself provided the regeneration of only $56 \%$ of healthy plants for PLRV, and of $62 \%$ for PVY.

The sanity of the micropropagated material is guaranteed by indexing tests. The ELISA test (Enzyme-Linked Immunosorbent Assay) has been widely adopted for this purpose, since it is fast and allows detecting virus persistence in a large number of regenerated plants (NAIK; BUCKSETH, 2018). Molecular techniques based on the use of primers for specific regions of the virus genome, such as RT-PCR, are also largely used (LORENZEN et al., 
2006; 2008; MUÑOZ et al., 2018; NIKITIN et al., 2018). In relation to the use of polyclonal antibodies, the technique involving RT-PCR has the advantage of differing strains and genetic variants, distinguishing the types of viral isolates. The indexation is of fundamental importance in the production chain of seed potatoes, as it ensures the quality of the material obtained by means of meristem culture, reflecting in field yield, which can be at least twice as high as the yield of plants derived from tubers (NAGIB et al., 2003).

The chemical composition and physical state of the culture medium may also interfere with potato in vitro multiplication. Regarding the chemical composition, the type of carbohydrate added to the culture medium affects explants survival, as verified by Fortes and Pereira (2001). In this work, higher survival rate was obtained when the carbon source was sucrose in detriment to the use of mannitol. Moreover, several studies mention that $3 \%$ of sucrose is the ideal concentration for the optimal micropropagation of potato, which, in addition to promoting greater biomass accumulation, favors the synthesis of sucrose, glucose and fructose, which may play an important role during potato plants acclimatization (WANG; HU, 1982; DONNELLY; COLEMAN; COLEMAN, 2003; BADR; ANGERS; DESJARDINS, 2011; BANDINELLI et al., 2013).

Although it has been reported that the use of growth regulators in potato meristem culture is dispensable (ROSELL et al., 1987; GOPAL; MINOCHA; DHALIWAL, 1998), the addition of indole-butyric acid, indole-acetic acid, and naphthalene-acetic acid, even at low concentrations, increases and accelerates the production of virusfree seedlings (GHAFFOOR; SHAH; WASEEM, 2003). These results corroborate those observed by Badoni and Chauhan (2009), who reported greater development and multiplication of potato seedlings when the culture medium was supplemented with $0.01 \mathrm{mg} \mathrm{L}^{-1}$ of naphthalene-acetic acid and $0.25 \mathrm{mg}$ $\mathrm{L}^{-1}$ of gibberellic acid.

Among the classes of plant regulators that are not widely used in in vitro cultivation, jasmonic acid, salicylic acid, ethylene, polyamines and brassinosteroids deserve attention. It is postulated that supplementation of the culture medium and/or the pretreatment of potato mother plants with jasmonic acid promotes in vitro tuberization and improves the quality of microtubers (PRUSKI; ASTATKIE; NOWAK, 2002; SARKAR; PANDEY; SHARMA, 2006). Moreover, this growth regulator confers higher rates of potato micropropagation, although not always a quantitative effect was observed (RAVNIKAR; GOGALA, 1990; RAVNIKAR; VILHAR; GOGALA, 1992; ZHANG et al., 2006; KUMLAY, 2016).

Salicylic acid, in concentrations from 30 to $120 \mathrm{mg} \mathrm{L}^{-1}$, has been used in association with mannitol $(87.6 \mathrm{mM})$ for the in vitro preservation of potato (FORTES; PEREIRA, 2001). In addition, ethylene is associated with the formation of hyperhydric structures (PARK et al., 2004), and the supplementation of the medium with ethylene synthesis inhibitors, such as silver thiosulfate, is often necessary (PERL; AVIV; GALUN, 1988; MÖLLERS; ZHANGM; WENZEL, 1992; SARKAR; KAUSHIK; NAIK, 1999; ZOBAYED; ARMSTRONG; ARMSTRONG, 2001; ROSTAMI; EHSANPOUR, 2010). Similarly to jasmonic acid, polyamines favor in vitro potato tuberization (PROTACIO; FLORES, 1992; FERAY et al., 1993; MADER, 1995), while brassinosteroids have been used in the induction of embryogenic calli (MORE et al., 2001), acclimatization (AGRAMONTE et al., 1996; PAVLOVNA et al., 2015), and proliferation (BASERA et al., 2018). Although researchers have already taken the first steps for the study of these regulators, there are gaps regarding the best concentrations and combinations at different stages of potato micropropagation.

In relation to the consistency, the liquid culture medium is more efficient in potato in vitro multiplication when compared with the semi-solid (PEREIRA; FORTES, 2003a). According to the same authors, higher biomass production is obtained when the material is cultivated in liquid medium composed of MS salts at full concentration, supplemented with pantothenic acid $\left(5.0 \mathrm{mg} \mathrm{L}^{-1}\right)$, thiamine $\left(1.0 \mathrm{mg} \mathrm{L}^{-1}\right)$, gibberellic acid $\left(0.25 \mathrm{mg} \mathrm{L}^{-1}\right)$, and sucrose $\left(20 \mathrm{~g} \mathrm{~L}^{-1}\right)$ under constant shaking. Similar result was observed for the organogenesis of potato meristematic apices (PEREIRA; FORTES, 2004b), in which the liquid culture medium had a higher multiplication rate when compared with the semi-solid medium.

However, a disadvantage of the cultivation in liquid medium is the occurrence of hyperhydricity. Hyperhidric structures were reported by Rosell et al. (1987) and Park et al. (2004) when studying potato micropropagation. Nevertheless, the authors observed that the formation of these structures can be avoided by transferring the culture to solid medium. Media are generally polymerized with agar or phytagel, though many alternative gelling agents, as Lallemantia royleana seeds, are proposed to reduce the costs of potato in vitro micropropagation (JABEEN; 
KAUSAR; SHAH, 2017). Besides the consistency, the concentration of salts, the type and the dose of cytokinins present in the medium also affect the formation of hyperhidric structures (PALMA et al., 2011).

Important aspects concerning incubation of micropropagated potato plants are addressed in some research. Those range from light sources (ROCHA; OLIVEIRA; SCIVITTARO, 2015), growth room ventilation (VENKATASALAM et al., 2015), and culture vessels (SHUKLA et al., 2017) until changes in plantlets profiles (GUPTA; PATTANAYAK, 2017; LOYOLA-VARGAS; OCHOA-ALEJO, 2018).

\section{Tuberization}

The transition between in vitro multiplication and the establishment of this solanaceous in the field is known as microtuberization (NISTOR et al., 2010). In this case, microtubers have been used as an alternative method for national and international distribution of potato germplasm and as pathogen-free starting material for seed multiplication programs (MUÑOZ, 1996). These small tubers have some advantages in relation to in vitro seedlings, such as: easy distribution and handling of the material due to its reduced size, greater resistance to transport conditions, and possibility of dark storage under low temperatures for longer periods than that of micropropagated seedlings (TOVAR et al., 1985; McCOWN; JOYCE, 1991). In addition, microtubers can be used as an explant source in studies on genetic transformation (SNYDER; BELKNAP, 1993).

Several protocols to induce in vitro tuberization have already been developed, such as that of Wang and $\mathrm{Hu}$ (1982), which is adopted by the International Potato Center (Centro Internacional de la Papa - CIP) (TOVAR et al., 1985; DODDS; SILVA-RODRIGUEZ; TOVAR, 1992). This protocol consists of adding 6benzylaminopurine, chlorocholine chloride and sucrose to the liquid culture medium. Tuberization can also be achieved in bioreactor systems, even resulting in greater yields and less hyperhydricity rates compared to the liquid culture (RAHMAN et al., 2015). The in vitro microtuber, subjected to proper stimuli, can further be directly seeded in open field (SHIN et al., 2018).

Microtubers ideal growing conditions (photoperiod, temperature, and nutrient source and dose) may vary according to the genotype under study. In this context, Gopal, Minocha and Dhaliwal (1998) evaluated 22 potato genotypes and verified, for most of the materials, the formation of microtubers under short photoperiod conditions (10 $\mathrm{h}$ photoperiod with irradiance of $12 \mu \mathrm{mol} \mathrm{m} \mathrm{m}^{-2} \mathrm{~s}^{-1}$ ) and low temperature $\left(20 \pm 2{ }^{\circ} \mathrm{C}\right.$ during the day and $18 \pm 2^{\circ} \mathrm{C}$ at night). In relation to the source and dose of carbon in the culture medium, $6 \%$ of sucrose and $4 \%$ of maltose were considered suitable for the potato in vitro tuberization, for cultivars Agria and Justine, respectively (ALTINDAL; KARADOGAN, 2010). Thus, genotype $\mathrm{x}$ environment interactions indicate the importance of developing specific protocols for each potato cultivar in order to maximize micropropagation, resulting in the availability of sufficient and high quality material for farmers.

\section{Production of indexed seed potato}

In Brazil, the official production process of pathogen-free seed potatoes begins with the in vitro production of plants from the shoot tip culture. The methodology for shoot-tip propagation depends, as in any micropropagation process as previously described, on asepsis, on the genotype of the plant material, on the explant itself, and on the composition of the culture medium in which the material will be inoculated.

Shoot tips are isolated and inoculated in medium containing more cytokinin than auxin for differentiation into aerial parts. Subsequently, these multiplicated shoots are transferred to the medium containing only cytokinin (or not). A shoot tip can generate from 500 to more than 1000 plants, depending on the cultivar or even on the shoot tip. Bandinelli et al. (2013) reported that the 50\% reduction in the MS salts concentration during multiplication increases the ex vitro survival rate in Asterix, Macaca, and SMINIA793101-3 potato clones. At the establishment and multiplication stages, plants are kept in a growth chamber, with light (14-16 $\mathrm{h}$ photoperiod) and temperature (25$27^{\circ} \mathrm{C}$ ) control (PEREIRA; FORTES, 2004b). Seedlings can be transferred to a medium richer in sucrose for in vitro tuberization. However, this procedure is not widely adopted. Instead, tuberization in a tray or plate with sterile substrate under anti-aphid conditions has been more frequently used. Bandinelli et al. (2013) recommend the mineral substrate (coarse sand), as it favors the acclimatization of the plants, increasing the survival rate in the field. However, according to Daniels, Pereira and Fortes (2000), the production of seed tubers in solid matrix presents low productive efficiency, since three to five tubers per plant are produced. 
Soil-free (or non-solid) technologies have gained attention and replaced the conventional production system of seed tubers. Factor et al. (2007) reported that these technologies prevent the contact of seed tubers with soil phytopathogens, facilitates cleaning after the production cycle, enables staggered harvesting, standardizes the tubers, and guarantees high phytosanitary quality and higher multiplication rate. Soil-free technologies include hydroponics, nutrient film technique, deep flow technique, and aeroponics. Among them, aeroponic systems have emerged as a possibility in many developing countries, such as Brazil (FACTOR et al., 2007), Peru (OTAZÚ, 2010), China (WANG et al., 2017), and Uganda (KAKUHENZIRE et al., 2017). Briefly, it consists of spraying a nutrient solution to the suspended plant roots and draining it back to the reservoir tanks until the next cycle of misting.

After cultivation, seed potatoes are stored at ambient conditions for 10 to 14 days for peel suberification and further stored for six to eight months, at 3 to $4^{\circ} \mathrm{C}$, for dormancy overcome and for the sprouting of the largest number of eyes. After this period, tubers are able to produce seed potatoes in the field, in isolated areas with low incidence of insect vectors, meeting certification standards (DUTRA et al., 2010).

The production and commercialization of seed potatoes within the Brazilian territory follow rules that aim at ensuring the genetic identity and health of this plant material, which are determined by the Ministry of Livestock and Food Supply (MAPA). According to the Normative Instruction No. 32 of November 20, 2012, of MAPA, seed potatoes should be produced in the following categories: genetic seed potatoes; basic seed potato (G0, G1, G2 and G3); certified seed potato of first generation (C1); certified seed potato of second generation (C2); S1 and S2. The basic seed potato G0 should be obtained from the genetic seed potato or from the basic potato seedling, cultivated in protected environment. The basic seed potato G1 should be obtained from the basic seed potato G0; the basic seed potato $\mathrm{G} 2$ should be obtained from the basic seed potato G1; and basic seed potato G3 should be obtained from the basic seed potato G2 Certified seed potatoes of first generation (C1) should be obtained from basic or certified seed potatoes, whereas certified seed potatoes $\mathrm{C} 2$ can be obtained from certified seed potatoes $\mathrm{C} 1$, basic seed potatoes, or from certified seedlings. S1 seed potatoes should be obtained from certified seed potatoes $\mathrm{C} 2$ or above; and $\mathrm{S} 2$ seed potato should be obtained from S1 seed potatoes, or from higher categories (MAPA, 2012).

In addition to the tuber, the shoot can also be used as propagative material in the production of basic and certified seed potatoes (MOREIRA, 2008), reducing costs with the production or acquisition of seed potatoes (SILVA et al., 2011; VIRMOND; KAWAKAMI; DIAS, 2011). The Normative Instruction No. 32 of November 20, 2012 establishes that certified seedlings in the form of sprouts can only be produced using basic seed potatoes (MAPA, 2012). In production of seedlings, minitubers and basic seed potatoes, their indexation by the ELISA test is mandatory, in order to confirm the absence of viruses.

\section{Somatic embryogenesis}

Several studies have reported the formation of potato somatic embryos in solid culture medium from tuber discs (BRAGDØ-AAS, 1977; NASSAR et al., 2011), nodal segments (GARCÍA; MARTÍNEZ, 1995; SEABROOK; DOUGLASS; TAI, 2001; VARGAS; GARCIA; OROPEZA, 2005; VARGAS et al., 2008; SHARMA et al., 2007, 2008b), and leaf tissues (JAYASREE et al., 2001; KAUR; REDDY; KUMAR, 2018). The formation of these structures in liquid medium was first described by Fiegert, Mix-Wagner and Vorlop (2000).

Growth regulators content and ratio are key factors on callus induction and somatic embryos initiation and development. The molecular and biochemical mechanisms behind these phenomena however are yet to be elucidated. For some information, consult Nassar, Kubow and Donnelly (2015). At the first stage, auxins are required to induce callusing but must be removed during embryo initiation due to their suppressive effect. The most frequent used is the 2,4dichlorophenoxyacetic acid (2,4-D) (BORDALLO et al., 2004; VARGAS; GARCIA; OROPEZA, 2005; VARGAS et al., 2008; SHARMA; MILLAM, 2004; SHARMA et al., 2007, 2008a, b; NASSAR et al., 2011; SABETI; ZARGHAMI; EBRAHIM, 2013). Embryo formation is later induced by a range of growth regulators, including zeatin and gibberellin $\left(\mathrm{GA}_{3}\right)$ (FIEGERT; MIX-WAGNER; VORLOP, 2000; JAYASREE et al., 2001; SEABROOK; DOUGLASS, 2001; SEABROOK; DOUGLASS; TAI, 2001; VARGAS; GARCIA; OROPEZA, 2005; VARGAS et al., 2008; SHARMA; MILLAM, 2004; SHARMA et al., 2007; SHARMA; SARKAR; PANDEY, 2010; NASSAR et al., 2011). 
Jayasree et al. (2001) established an efficient protocol to induce somatic embryos and regenerate potato seedlings, cv. Jyothi, from leaf segments. Initially, leaves are grown in MS medium supplemented with 2,4-D and benzyladenine (BA). The embryogenic calli, obtained from the borders of the leaf segments, are transferred to MS medium containing zeatin and BA, resulting in high formation of somatic embryos. Embryos mature in the same induction medium, and are transferred to MS medium without growth regulators for seedling regeneration when they reach the cotyledonary stage.

Seabrook and Douglass (2001) also reported the in vitro induction of somatic embryos of 18 tetraploid potato cultivars from several explants (nodal segments, leaves, microtubers, and roots). These authors observed differences in induction capacity depending on the genotype of the evaluated materials, varying from 2.2 to 44.5 somatic embryos.

This technique, when applied to potato crop, is a potentially effective method in the production of synthetic seeds. Synseeds produce virus-free, trueto-type materials that are easy to handle and transport (POND; CAMERON, 2003; BORDALLO et al., 2004; SHARMA et al., 2007). However, there has been relatively little progress on this application due to problems of somaclonal variation and requirement of bioreactors for large-scale production of somatic embryos followed by their encapsulation and field planting (FIEGERT; MIXWAGNER; VORLOP, 2000; NYENDE et al., 2002; SCHAFER-MENUHR; MIX-WAGNER; VORLOP, 2003, BAMBERG et al., 2016). Thus, the development of reliable systems of somatic embryogenesis for this solanaceous plant is still incipient (SHARMA; MILLAM, 2004), and few studies are found in the literature regarding the occurrence and performance of somaclones in greenhouse (SEABROOK; DOUGLASS, 2001) and in field (NASSAR, 2009; NASSAR et al., 2014) and the genetic mechanisms that regulate this process (SHARMA et al., 2008a, b).

\section{Protoplast culture}

Protoplast technology has focused especially on the generation of interspecific hybrids between wild and cultivated species that cannot be produced via conventional hybridization (DAVEY et al., 2005). In potato culture, wild Solanum species are commonly used to introduce desirable traits to commercial genotypes.

In 1987, Fish, Karp and Jones developed a protoplast culture technique applicable to several dihaploid potato genotypes. The protoplasts were isolated from $S$. tuberosum mesophilic cells and from the wild diploid species $S$. brevidens, and fused together at high $\mathrm{pH}$ and high calcium concentrations. Putative hybrids were then selected by the phenotype from regenerated shoots, and of these, 11 somatic hybrids were identified in function of their isoenzymatic patterns and morphological traits.

By means of somatic hybridization, several resistance genes from wild species have already been introduced into potato, including those that confer tolerance to herbicide (BINDING et al., 1982), resistance to leafroll virus (AUSTIN; BAER; HELGESON, 1985), tolerance to frost (ROKKA et al., 1998), tolerance to late blight disease (SHI et al., 2006), and resistance to insects (CHENG; SAUNDERS; SINDEN, 1995; BUTLER et al., 2011; DIAZ-MONTANO et al., 2014). Specific reviews of somatic hybridization in potato can be found in Pandey et al. (2010), Cho and Park (2014) and Rokka (2015).

\section{In vitro preservation and cryopreservation}

The maintenance of in vitro collections has been considered an alternative method to the conservation of germplasm, especially for vegetative propagated species. In the case of potato, the minimum in vitro growth occurs by the control of incubation conditions, such as low temperatures, low light intensity, and mixed photoperiod (WESTCOTT, 1981a; GOPAL; CHAUHAN, 2010), or by the addition of substances to the culture medium, especially growth retardants and osmotic stress inducers (WESTCOTT, 1981b; FORTES; PEREIRA, 2001; GOPAL; CHAUHAN, 2010).

Sarkar and Naik (1998) studied the effect of simultaneous manipulation of incubation conditions and culture medium on the in vitro preservation of four potato genotypes. The combination of $40 \mathrm{~g} \mathrm{~L}^{-1}$ sucrose, $20 \mathrm{~g} \mathrm{~L}^{-1}$ mannitol, and $16 \mathrm{~h}$ photoperiod provided better conservation of potato microplants for up to 30 months without the need for subcultivation. Alternatively to mannitol, ancimidol - a growth retardant - can be used (SARKAR; CHAKRABARTI; NAIK, 2001). At CIP, more than 4,000 potato accessions are kept in culture medium with $40 \mathrm{~g} \mathrm{~L}^{-1}$ sorbitol and under low temperature (6$8^{\circ} \mathrm{C}$ ) (NIINO; ARIZAGA, 2015), as similarly observed at the US Potato Genebank $\left(30 \mathrm{~g} \mathrm{~L}^{-1}\right.$ sorbitol, $8-10^{\circ} \mathrm{C}$ ) (BAMBERG et al., 2016). In the case of liquid culture medium, González-Benito, Ramírez and Aranda (2004) reported that supplementation of MS medium with $2 \%$ sucrose 
and incubation at $10^{\circ} \mathrm{C}$ allows the maintenance of potato seedlings for about 2-3 years.

The choice of the conservation method to be used should consider the occurrence of somaclonal variation, which may also be associated with the nature of the plant material and to the substances employed (WITHERS; ENGELMANN, 1998). This genetic variation needs to be evaluated at the end of the whole process in order to detect possible threats to the genetic stability of plant material. As an example, Harding (1994) detected hypermethylation of potato microplants' DNA maintained for long periods under osmotic stress promoted by the use of mannitol. Conversely, Sarkar, Chakrabarti and Naik (2001) detected no genetic instability after 16 months of conservation by means of Random Amplified Polymorphic DNA (RAPD) markers, when evaluating the effects of ancimidol on the conservation of potato microplants.

Long-period in vitro preservation may not guarantee the genetic stability of the micropropagated material. Thus, cryopreservation is a more reliable alternative. In addition to long-term storage of potato germplasm, cryotherapy can simultaneously be applied as an alternative method for virus elimination and production of indexed plants (WANG et al., 2006; KACZMARCZYK; ROKKA; KELLER, 2011).

The first report on the use of this technique in potatoes was in the late 1970s (BAJAJ, 1977), and from that work, different methods have been developed using slow or ultrafast freezing (TOWILL, 1984; BENSON; HARDING; SMITH, 1989). In 1995, CIP started to test a cryopreservation method by vitrification. The process consisted of dehydrating potato meristems in concentrated sugar solutions and cryoprotectors and rapidly freezing them using liquid nitrogen (GOLMIRZAIE; PANTA, 2000). Other techniques of vitrification have already been tested for several potato cultivars, such as the encapsulationvitrification method (HIRAI; SAKAI, 1999; HIRAI, 2011), the droplet-vitrification (KIM et al., 2006; YOON et al., 2006), and the V-cryo-plate (YAMAMOTO et al., 2013).

The viability of potato shoot tips maintained for long periods in liquid nitrogen has also been reported (MIX-WAGNER; SHUMACHER; CROSS, 2003). These authors compared the regeneration of 51 cultivars in long-term (3 to 8 years) and short-term preservation. Only for three genotypes the cryopreserved shoot tips presented a significant decrease in regeneration.

\section{CONCLUSIONS}

Plant tissue culture techniques have been widely used as an alternative to solve the lack of propagating material of potatoes with high phytosanitary quality. Among these techniques, micropropagation stands out, whose clonal multiplication protocols have already been well established, and whose process is considered the main route of production of pathogen-free seed potatoes.

The use of somatic embryos has long been considered promising alternative to conventional potato propagules; however, little has been achieved in the development of synthetic seeds for this solanaceous plant. Thus, aspects concerning the application of somatic embryogenesis in this species still require further studies. In addition, more studies should address the viability of potato genetic transformation via culture and protoplast fusion.

In addition to large-scale clonal production of indexed plants, in vitro techniques can be employed for medium-term preservation and safe exchange of potato germplasm. Thus, cryopreservation can be considered an additional tool for genetic material conservation.

Finally, the use of the products generated by scientific research by the different segments in the potato production chain is directly dependent on regular investments in the sector, and on the constant technical training of the professionals involved in research. Only then will potato be assisted with technology capable of guaranteeing highly productive crops.

\section{ACKNOWLEDGEMENTS}

This research was supported by the Coordenação de Aperfeiçoamento de Pessoal de Nível Superior - CAPES, Conselho Nacional de Desenvolvimento Científico e Tecnológico - CNPq, and Fundação de Amparo à Pesquisa do Estado de Minas Gerais - FAPEMIG. The first author would like to thank CAPES and Programa de PósGraduação em Agronomia (PPGA-UFU) for the financial support. 
RESUMO: A batata é a cultura não-cereal mais importante do mundo e, portanto, uma das principais fontes de alimento para a humanidade. Sua multiplicação convencional é assexuada utilizando o próprio tubérculo, o que permite o acúmulo e a difusão de patógenos para novas áreas de cultivo, comprometendo a produtividade desta solanácea e ameaçando a manutenção de genótipos de interesse comercial ou para fins de melhoramento. Devido à inviabilidade de utilização das sementes botânicas, a conservação e o intercâmbio de germoplasma dessa espécie por meio de métodos convencionais torna-se inviável. Em todas as regiões produtoras de batata, a demanda por tubérculos de alta qualidade tem sido primordial para garantir a produção das lavouras. Dessa forma, técnicas biotecnológicas baseadas na cultura de tecidos são de suma importância. A cultura de tecidos vegetais oferece métodos alternativos de propagação através das técnicas in vitro que proporcionam a produção e multiplicação de material com alta sanidade. Dessa maneira, esta revisão visa sumarizar o histórico e panorama atual das aplicações da cultura de tecidos em batata. Além da multiplicação clonal, essa ferramenta biotecnológica fornece material inicial indexado para programas de melhoramento e de produção certificada de batata-semente e facilita o intercâmbio e a conservação de germoplasma. Por tudo isso, o emprego destas técnicas na cadeia produtiva da batata proporciona benefícios diretos aos produtores, uma vez que fornece material propagativo com elevada qualidade genética e fitossanitária.

PALAVRAS-CHAVE: Solanum tuberosum L. Cultivo in vitro. Batata-semente. Erradicação de patógenos.

\section{REFERENCES}

AGRAMONTE, D.; JIMÉNEZ, F.; PÉREZ, M.; GUTIÉRREZ, O.; RAMIREZ, D.; NUÑEZ, M. Empleo de sustancias bioestimuladoras (Biobras-6 y Biobras-16) en la fase de adaptación de vitroplantas de papa (Solanum tuberosum L.). La Habana: INCA, 1996. 162p.

ALI, S.; KHAN, N.; NOUROZ, F.; ERUM, S.; NASIM, W.; SHAHID, M. A. In vitro effects of $\mathrm{GA}_{3}$ on morphogenesis of CIP potato explants and acclimatization of plantlets in field. In Vitro Cellular and

Developmental Biology Plant, v. 54, n. 1, p. 104-111, 2018. https://doi.org/10.1007/s11627-017-9874-x

ALTINDAL, D.; KARADOGAN, T. The effect of carbon sources on in vitro microtuberization of potato (Solanum tuberosum L.). Turkish Journal of Field Crops, v. 15, n. 1, p. 7-11, 2010.

AUSTIN, S.; BAER, M. A.; HELGESON, J. P. Transfer of resistance to Potato leaf roll virus from Solanum brevidens into Solanum tuberosum by somatic fusion. Plant Science, v. 39, p. 75-82, 1985.

https://doi.org/10.1016/0168-9452(85)90195-5

ÁVILA, A.; PEREYRA, S. M.; COLLINO, D. J.; ARGÜELLO, J. A. Effects of nitrogen source on growth and morphogenesis of three micropropagated potato cultivars. Potato Research, v. 37, n. 2, p. 161-168, 1994. https://doi.org/10.1007/BF02358717

BADONI, A.; CHAUHAN, J. S. Effect of growth regulators on meristem-tip development and in vitro multiplication of potato cultivar 'kufri himalini'. Nature and Science, v. 7, n. 9, p. 31-34, 2009.

BADR, A.; ANGERS, P.; DESJARDINS, Y. Metabolic proofing of photoautotrophic and photomixotrophic potato plantles (Solanum tuberosum) provides new insights into acclimatization. Plant Cell, Tissue and Organ Culture, v. 107, p. 13-24, 2011. https://doi.org/10.1007/s11240-011-9951-5

BAJAJ, Y. P. S. Initiation of shoots and callus from potato-tuber sprouts and axillary buds frozen at $-196^{\circ} \mathrm{C}$. Crop Improvement, v. 4, p. 48-53, 1977.

BAMBERG, J. B.; MARTIN, M. W.; ABAD, J.; JENDEREK, M. M., TANNER, J.; DONNELLY, D. J.; NASSAR, A. M. K.; VEILLEUX, R. E.; NOVY, R. G. In vitro technology at the US Potato Genebank. In Vitro Cellular and Developmental Biology Plant, v. 52, n. 3, p. 213-225, 2016. https://doi.org/10.1007/s11627-016-9753-X 
BANDINELLI, M. G.; BISOGNIN, D. A.; GNOCATO, F. S.; MAMBRIN, R. B.; SAUSEN, D.; NICOLOSO, F. T. Concentração dos sais e da sacarose do meio MS na multiplicação in vitro e na aclimatização de batata. Horticultura Brasileira, v. 31, n. 2, p. 242-247, 2013. https://doi.org/10.1590/S0102-05362013000200011

BASERA, M.; CHANDRA, A.; KUMAR, V. A.; KUMAR, A. Effect of brassinosteroids on in vitro proliferation and vegetative growth of potato. The Pharma Innovation Journal, v. 7, n. 4, p. 4-9, 2018.

BENSON, E. E.; HARDING, K.; SMITH, H. Variation in recovery of cryopreserved shoot tips of Solanum tuberosum exposed to different pre- and post-freeze light regimes. CryoLetters, v. 10, p. 323-344, 1989.

BINDING, H.; JAIN, S. M.; FINGERINGER, J.; MORDHORST, G.; NEHLS, R.; GRESSEL, J. Somatic hybridization of an atrazine resistant biotype of Solanum nigrum with Solanum tuberosum. Theoretical and Applied Genetics, v. 63, n. 3, p. 273-277, 1982. https://doi.org/10.1007/BF00304007

BORDALLO, P. N.; SILVA, D. H.; MARIA, J.; CRUZ, C. D.; FONTES, E. P. Somaclonal variation on in vitro callus culture potato cultivars. Horticultura Brasileira, v. 22, p. 300-304, 2004.

https://doi.org/10.1590/S0102-05362004000200027

BRAGDØ-AAS, M. Regeneration of plants from callus of potato tubers. Acta Horticulturae, v. 78, p. 133138, 1977. https://doi.org/10.17660/ActaHortic.1977.78.16

BUTLER, C. D.; GONZALEZ, B.; MANJUNATH, K. L.; LEE, R. F.; NOVY, R. G.; MILLER, J. C.; TRUMBLE, J. T. Behavioral responses of adult potato psyllid, Bactericera cockerelli (Hemiptera: Triozidae), to potato germplasm and transmission of Candidatus Liberibacter psyllaurous. Crop Protection, v. 30, p. 1233-1238, 2011. https://doi.org/10.1016/j.cropro.2011.05.006

CEARLEY, T. A.; BOLYARD, M. G. Regeneration of Solanum tuberosum cv. Katahdin from leaf explants in vitro. American Journal of Potato Research, v.74, n.2, p.125-129, 1997. https://doi.org/10.1007/BF02851558

CHENG, J. J.; SAUNDERS, A.; SINDEN, S. L. Colorado potato beetle resistant somatic hybrid potato plants produced via protoplast electrofusion. In Vitro Cellular and Developmental Biology Plant, v. 31, n. 2, p. 90 95, 1995. https://doi.org/10.1007/BF02632243

CHO, K. S.; PARK, T. H. Potato breeding via protoplast fusion. Journal of Plant Biotechnology, v. 41, p. 6572, 2014 (in Korean with English abstract). https://doi.org/10.5010/JPB.2014.41.2.65

DANIELS, J.; PEREIRA, A. S.; FORTES, G. R. L. Verticalização da produção de batata-semente por produtores de agricultura familiar no Rio Grande do Sul. Pelotas: Embrapa Clima Temperado, 2000. 4p.

DAVEY, M. R.; ANTHONY, P.; POWER, J. B.; LOWE, K. C. Plant protoplasts: status and biotechnological perspectives. Biotechnology Advances, v. 23, n. 2, p. 131-171, 2005.

https://doi.org/10.1016/j.biotechadv.2004.09.008

DIAZ-MONTANO, J.; VINDIOLA, B. G.; DREW, N.; NOVY, R. G.; MILLER, J. C.; TRUMBLE, J. T. Resistance of selected potato genotypes to the potato psyllid (Hemiptera: Triozidae). American Journal of Potato Research, v. 91, p. 363-367, 2014. https://doi.org/10.1007/s12230-013-9356-6

DODDS, J. H.; SILVA-RODRIGUEZ, D.; TOVAR, P. Micropropagation of potato (Solanum tuberosum L.). In: BAJAJ, Y. P. S. (Ed.). Biotechnology in Agriculture and Forestry. High-Tech and Micropropagation III. New York, Heidelberg, Berlin: Springer, 1992. v. 19, p. 91-205. https://doi.org/10.1007/978-3-662-07770-2_6

DONNELLY, D. J.; COLEMAN, W. K.; COLEMAN, S. E. Potato microtuber production and performance: a review. American Journal of Potato Research, v. 80, n. 2, p. 103-115, 2003. https://doi.org/10.1007/BF02870209 
DUTRA, L. F.; MAYER, K. C. A.; SILVA, N. D. G.; NINO, A. F. P.; SILVA, F. O. X.; VIEIRA, F. C. B. Protocolo de Micropropagação de Plantas. I - Batata. Pelotas: Embrapa Clima Temperado, 2010. 22p.

EL-FIKI, A. I. I.; EL DIN, T. M. N.; MAHDY, A. M. M.; ALI, A. S. Elimination of Potato virus X and comparable of microtuber productivity of some infected potatoes in vitro. Annals of Agricultural Science, v. 30, n. 1, p. 195-208, 1992.

ESNA-ASHARI, M.; VILLIERS, T. A. Plant regeneration from tuber disc of potato (Solanum tuberosum L.) using 6-benzylaminopurine (6-BAP). Potato Research, v. 41, n. 4, p. 371-382, 1998.

https://doi.org/10.1007/BF02358969

FACTOR, T. L.; ARAÚJO, J. A. C.; KAWAKAMI, F. P. C.; IUNCK, V. Produção de minitubérculos básicos de batata em três sistemas hidropônicos. Horticultura Brasileira, v. 25, n. 1, p. 82-87, 2007.

https://doi.org/10.1590/S0102-05362007000100016

FERAY, A.; HOURMANT, A.; BRUN, A.; PENOT, M. Effect of polyamines on morphogenesis of in vitro potato plants (Solanum tuberosum cv. Bintje). Comptes Rendus de L'Académie des Sciences, v. 316, n. 12, p. 1446-1451, 1993.

FIEGERT, A. K.; MIX-WAGNER, G.; VORLOP, K. D. Regeneration of Solanum tuberosum L. cv. Tomensa: induction of somatic embryogenesis in liquid culture for the production of "artificial seed". Landbauforsch Völkenrode, v. 50, n. 3-4, p. 199-202, 2000.

FISH, N.; KARP, A.; JONES, M. G. K. Improved isolation of dihaploid Solanum tuberosum protoplasts and the production of somatic hybrids between dihaploid S. tuberosum and S. brevidens. In Vitro Cellular and Developmental Biology Plant, v. 23, n. 8, p. 575-580, 1987. https://doi.org/10.1007/BF02620975

FORTES, G. R. L.; PEREIRA, J. E. S. Batata-semente pré-básica: Cultura de Tecidos. In: PEREIRA, A. S.; DANIELS, J. (Eds). O cultivo da batata na região sul do Brasil. Brasília: Embrapa Informação Tecnológica, 2003a. p. 421-433.

FORTES, G. R. L.; PEREIRA, J. E. S. Classificação e descrição botânica. In: PEREIRA, A. S.; DANIELS, J. (Eds). O cultivo da batata na região sul do Brasil. Brasília: Embrapa Informação Tecnológica, 2003b. p. 53143.

FORTES, G. R. L.; PEREIRA, J. E. S. Preservação in vitro da batata com ácido acetilsalicílico e duas fontes de carboidrato. Pesquisa Agropecuária Brasileira, v. 36, n. 10, p. 1261-1264, 2001.

https://doi.org/10.1590/S0100-204X2001001000007

GARCÍA, E. D.; MARTÍNEZ, S. Somatic embryogenesis in Solanum tuberosum L. cv. Desiree from stem nodal sections. Journal of Plant Physiology, v. 145, p. 526-530, 1995. https://doi.org/10.1016/S01761617(11)81782-7

GHAFFOOR, A.; SHAH, G. B.; WASEEM, K. In vitro response of potato (Solanum tuberosum L.) to various growth regulators. Biotechnology, v. 2, n. 3, p. 191-197, 2003. https://doi.org/10.3923/biotech.2003.191.197

GOLMIRZAIE, A. M.; PANTA, A. Advances in potato cryopreservation at CIP. In: ENGELMANN, F.; TAKAGI, H. (Eds). Cryopreservation of tropical plant germplasm: current research progress and application. Tsukuba: JIRCAS/ Rome: IPGRI, 2000. p. 250-254.

GONÇALVES, J. F.; MALDANER, J.; ROSSATO, L. V.; TABALDI, L. A.; SKREBSKY, E. C.; FARIAS, J. G.; BISOGNIN, D. A.; NICOLOSO, F. T. Crescimento in vitro de plântulas de batata em diferentes doses de cádmio. Ciência Rural, v. 39, n. 9, p. 2625-2628, 2009. https://doi.org/10.1590/S0103-84782009000900038 
GONZÁLEZ-BENITO, M. E. G.; RAMÍREZ, I. C.; ARANDA, J. M. L. Review. The use of cryopreservation for germplasm conservation of vegetatively propagated crops. Spanish Journal of Agricultural Research, v. 2, n. 3, p. 341-351, 2004. https://doi.org/10.5424/sjar/2004023-88

GOPAL, J.; CHAUHAN, N. S. Slow growth in vitro conservation of potato germplasma at low temperature.

Potato Research, v. 53, n. 3, p. 141-149, 2010. https://doi.org/10.1007/s11540-010-9158-x

GOPAL, J.; MINOCHA, J. L.; DHALIWAL, H. S. Microtuberization in potato (Solanum tuberosum L.). Plant Cell Reports, v. 17, n. 10, p. 794-798, 1998. https://doi.org/10.1007/s002990050485

GRATTAPAGLIA, D.; MACHADO, M. A. Micropropagação. In: TORRES, A. C.; CALDAS, L. S.; BUSO, J. A. (Eds). Cultura de tecidos e transformação genética de plantas. Brasília: Embrapa-SPI, 1998. v. 1, p. 183260.

GUPTA, S. D.; PATTANAYAK, A. K. Intelligent image analysis (IIA) using artificial neural network (ANN) for non-invasive estimation of chlorophyll content in micropropagated plants of potato. In Vitro Cellular and Developmental Biology Plant, v. 53, n. 6, p. 520-526, 2017. https://doi.org/10.1007/s11627-017-9825-6

HARDING, K. The methylation status of DNA derived from potato plants recovered from slow growth. Plant Cell, Tissue and Organ Culture, v. 37, p. 31-38, 1994. https://doi.org/10.1007/BF00048114

HIRAI, D. Gelled droplet vitrification improves recovery of cryopreserved potato germplasm. CryoLetters, v. 32, n. 4, p. 287-296, 2011.

HIRAI, D.; SAKAI, A. Cryopreservation of in vitro-grown meristems of potato (Solanum tuberosum L.) by encapsulation-vitrification. Potato Research, v. 42, n. 1, p. 153-160, 1999.

https://doi.org/10.1007/BF02358405

IBGE - INSTITUTO BRASILEIRO DE GEOGRAFIA E ESTATÍSTICA. Levantamento sistemático da produção agrícola: pesquisa mensal de previsão e acompanhamento das safras agrícolas no ano civil. Rio de Janeiro: IBGE, 2017. 112p.

JABEEN, T.; KAUSAR, R.; SHAH, A. H. Development of low cost protocol for micropropagation of Solanum tuberosum L. Bangladesh Journal of Botany, v. 46, n. 4, p. 1341-1345, 2017.

JAYASREE, T.; PAVAN, U.; RAMESH, M.; RAO, A. V.; REDDY, J. M.; SADANANDAM, A. Somatic embryogenesis from leaf cultures of potato. Plant Cell, Tissue and Organ Culture, v. 64, n. 1, p. 13-17, 2001. https://doi.org/10.1023/A:1010697608689

KACZMARCZYK, A.; ROKKA, V. M.; KELLER, E. R. J. Potato shoot tip cryopreservation. Potato Research, v. 54, p. 45-79, 2011. https://doi.org/10.1007/s11540-010-9169-7

KAKUHENZIRE, R.; TIBANYENDERA, D.; KASHAIJA, I. N.; LEMAGA, B.; KIMOONE, G.; KESIIME, V. E.; OTAZU, V.; ORTIZ, O.;BARKER, I. Improving minituber production from tissue-cultured potato plantlets with aeroponic technology in Uganda. International Journal of Agriculture and Environmental Research, v. 3, n. 5, p. 3948-3964, 2017.

KAUR, A.; REDDY, M. S.; KUMAR, A. Direct somatic embryogenesis of potato [Solanum tuberosum (L.)] cultivar 'Kufri Chipsona 2'. Plant Cell, Tissue and Organ Culture, p. 1-10, 2018.

https://doi.org/10.1007/s11240-018-1435-4

KAUR, A.; REDDY, M. S.; KUMAR, A. Efficient, one step and cultivar independent shoot organogenesis of potato. Physiology and Molecular Biology of Plants, v. 23, n. 2, p. 461-469, 2017.

https://doi.org/10.1007/s12298-017-0418-y 
KIM, H. H.; YOON, J.; PARK, Y.; CHO, E.; SOHN, J.; KIM, T.; ENGELMANN, F. Cryopreservation of potato cultivated varieties and wild species: critical factors in droplet vitrification. CryoLetters, v. 27, n. 4, p. 223-234, 2006.

KUMLAY, A. M. The effect of jasmonic acid on the micropropagation of potato (Solanum tuberosum L.) under long days conditions. YYU Journal of Agricultural Sciences, v. 26, n. 1, p. 79-88, 2016.

LEIFERT, C.; WOODWARD, S. Laboratory contamination management: the requirement for microbiological quality assurance. Plant Cell, Tissue and Organ Culture, v. 52, n. 1, p. 83-88, 1998.

https://doi.org/10.1023/A:1005905604043

LORENZEN, J. H.; NOLTE, P.; MARTIN, D.; PASCHE, J. S.; GUDMESTAD, N. C. NE-11 represents a new strain variant class of Potato virus Y. Archives Virology, v. 153, p. 517-525, 2008.

https://doi.org/10.1007/s00705-007-0030-5

LORENZEN, J. H.; PICHIE, L. M.; GUDMESTAD, N. C.; MEACHAM, T.; SCHIEL, P. A multiplex PCR assay to characterize Potato virus Y isolates and identify strain mixtures. Pant Disease, v. 90, p. 935-940, 2006. https://doi.org/10.1094/PD-90-0935

LOYOLA-VARGAS, V. M.; OCHOA-ALEJO, N. An introduction to plant tissue culture: advances and perspectives. In: LOYOLA-VARGAS, V.; OCHOA-ALEJO, N. (Eds). Plant Cell Culture Protocols: Methods in molecular biology. New York: Humana Press, 2018. p. 3-13. https://doi.org/10.1007/978-1-49398594-4 https://doi.org/10.1007/978-1-4939-8594-4_1

MADER, J. C. Polyamines in Solanum tuberosum in vitro: free and conjugated polyamines in hormoneinduced tuberization. Journal of Plant Physiology, v. 146, p. 115-120, 1995. https://doi.org/10.1016/S01761617(11)81976-0

MAPA - MINISTÉRIO DA AGRICULTURA, PECUÁRIA E ABASTECIMENTO. Instrução normativa 32/2012: Normas gerais para certificação de batata-semente. Brasília, DF, 2012. 15p.

McCOWN, B.; JOYCE, P. Automated propagation of microtubers of potato. In: VASIL, I. (Ed.). Cell culture and somatic cell genetics of plants. San Diego: Academic Press, 1991. v. 8, p. 235.

https://doi.org/10.1016/B978-0-12-715008-6.50012-9

MENEZES, C. B.; PINTO, C. A. B. P.; NURMBERG, P. L.; LAMBERT, E. S. Avaliação de genótipos de batata (Solanum tuberosum L.) nas safras "das águas" e de inverno no sul de Minas Gerais. Ciência e Agrotecnologia, v. 23, n. 4, p. 776-783, 1999.

MIX-WAGNER, G.; SHUMACHER, H. M.; CROSS, R. J. Recovery of potato apices after several years of storage in liquid nitrogen. CryoLetters, v. 24, n. 1, p. 33-41, 2003.

MÖLLERS, C.; ZHANGM, S.; WENZEL, G. The influence of silver thiosulfate on potato protoplast cultures. Plant Breeding, v. 108, n. 1, p. 12-18, 1992. https://doi.org/10.1111/j.1439-0523.1992.tb00094.x

MORE, O.; HERNANDEZ, M.; NUNEZ, M.; ESTEVEZ, A.; GONZALEZ, M. E. Empleo de analogos de brassinosteroides en la formacion de callus embriogenicos en papa (Solanum tuberosum L.). Cultivos Tropicales, v. 224, p. 29-35, 2001.

MOREIRA, M. A. Característica da planta e produção de batata semente básica em substrato com diferentes materiais de propagação. 2008. 174f. Tese (Doutorado em Fitotecnia) - Universidade Federal de Viçosa, Viçosa, Brasil. 
MUÑOZ, G. D. C. J. Propagación in vitro y microtuberización de cultivares de Solanum tuberosum L. ssp. tuberosum Hawkes en medios liquidos. 1996. 91f. Dissertação (Mestrado em Ciências/Botânica) Universidad Austral de Chile, Valdivia, Chile.

MUÑOZ, M. A.; KALAZICH, J. C.; FOLCH, C. V.; ORENA, S. V.; WINKLER, A. The use and impact of biotechnology in potato breeding: experience of the Potato Breeding Program at INIA, Chile. In: YILDIZ, M. (Ed.). Potato: from Incas to all over the world. London: Intech Open, 2018. p. 3-17.

https://doi.org/10.5772/intechopen.72961

NAGIB, A.; HOSSAIN, S. A.; ALAM, M. F.; HOSSAIN, M. M.; ISLAM, R.; SULTANA, R. S. Virus free potato tuber seed production through meristem culture in tropical Asia. Asian Journal of Plant Sciences, v. 2, p. 616-622, 2003. https://doi.org/10.3923/ajps.2003.616.622

NAIK, P. S.; BUCKSETH, T. Recent advances in virus elimination and tissue culture for quality potato seed production. In: GOSAL, S.; WANI, S. (Eds). Biotechnologies of crop improvement. Cham: Springer, 2018. Volume 1. p. 131-158. https://doi.org/10.1007/978-3-319-78283-6_4

NASCIMENTO, L. C.; PIO-RIBEIRO, G.; WILLADINO, L.; ANDRADE, G. P. Stock indexing and Potato virus Y elimination from potato plants cultivated in vitro. Scientia Agricola, v. 60, n. 3, p. 525-530, 2003. https://doi.org/10.1590/S0103-90162003000300017

NASSAR, A. M. K.; ABDULNOUR, J.; LECLERC, Y.; LI, X-Q.; DONNELLY, D. J. Intraclonal selection for improved processing of NB 'Russet Burbank' potato. American Journal of Potato Research, v. 88, p. 387 397, 2011. https://doi.org/10.1007/s12230-011-9204-5

NASSAR, A. M. K.; KUBOW, S.; DONNELLY, D. J. Somatic embryogenesis for potato (Solanum tuberosum L.) improvement. In: LI, X-Q; DONNELLY, D. J.; JENSEN, T. G. (Eds). Somatic genome manipulation: Advances, methods, and applications. New York, Heidelberg, Dordrecht, London: Springer, 2015. p. 169-198.

NASSAR, A. M. K.; KUBOW, S.; LECLERC, Y. N.; DONNELLY, D. J. Somatic mining for phytonutrient improvement of 'Russet Burbank' potato. American Journal of Potato Research, v. 91, p. 89-100, 2014. https://doi.org/10.1007/s12230-013-9334-z

NASSAR, A. M. K. Use of somatic embryogenesis in potato (Solanum tuberosum L.) cv. Russet Burbank improvement. 2009. 192f. Tese (Doutorado em Fitotecnia) - McGill University, Montreal, Canada.

NIINO, T.; ARIZAGA, M. V. Cryopreservation for preservation of potato genetic resources. Breeding Science, v. 65, n. 1, p. 41-52, 2015. https://doi.org/10.1270/jsbbs.65.41

NIKITIN, M. M.; STATSYUK, N. V.; FRANTSUZOV, P. A.; DZHAVAKHIYA, V. G.; GOLIKOV, A. G. Matrix approach to the simultaneous detection of multiple potato pathogens by real-time PCR. Journal of Applied Microbiology, v. 124, p. 797-809, 2018. https://doi.org/10.1111/jam.13686

NISTOR, A.; CÂMPEANU, G.; ATANASIU, N.; CHIRU, N.; CARACSONIY, D. Influence of potato genotypes on "in vitro" production of microtubers. Romanian Biotechnological Letters, v. 15, n. 3, p. 53175324, 2010.

NYENDE, A. B.; SCHITTENHELM, S.; MIX-WAGNER, G.; GREEF, J. M. Synthetic potato seeds offer the potential to improve Kenyan seed system. Landbauforsch Volk, v. 42, p. 141-148, 2002.

OTAZÚ, V. Manual on quality seed potato production using aeroponics. Lima: International Potato Center (CIP), 2010. 44p. https://doi.org/10.4160/9789290603924 
PALMA, D.; SCHUELTER, A. R.; STEFANELLO, S.; FORTES, A. M. T. Aspectos morfofisiológicos e controle da hiperhidricidade na cultura de tecidos vegetais. Revista Brasileira de Agrociências, v. 17, n. 2-4, p. 174-184, 2011.

PANDEY, S. K.; SARKAR, D.; SHARMA, S.; CHANDEL, P. Integration of somatic fusion into potato breeding: problems and perspectives. American Potato Journal, v.37, p.9-20, 2010.

PARK, S. W.; JEON, H. H.; KIM, H. S.; PARK, Y. M.; ASWATH, C.; JOUNG, H. Effect of sealed and vented gaseous microenvironments on the hyperhydricity of potato shoots in vitro. Scientia Horticulturae, v. 99, p. 199-205, 2004. https://doi.org/10.1016/S0304-4238(03)00097-9

PAVLOVNA, U. I.; NIKOLAEVNA, K. N.; VLADIMIROVNA, D. E.; VENIAMINOVNA, S. O.; ALEKSANDROVICH, S. D. Brassinosteroids as a factor of photosyntetic activity increase of improved potatoes. Biosciences Biotechnology Research Asia, v. 12, n. 2, p. 1481-1485, 2015. https://doi.org/10.13005/bbra/1807

PEREIRA, J. E. S.; FORTES, G. R. L. Multiplicación in vitro de la papa en medio sólido y líquido: influencia de diferentes medios de cultura. Horticultura Argentina, v. 19, n. 46, p. 24, 2000.

https://doi.org/10.1590/S0100-204X2003000900003

PEREIRA, J. E. S.; FORTES, G. R. L. Protocolo para produção de material propagativo de batata em meio líquido. Pesquisa Agropecuária Brasileira, v. 38, n. 9, p. 1035-1043, 2003a. https://doi.org/10.1590/S0100204X2003001100004

PEREIRA, J. E. S.; FORTES, G. R. L. Toxicidade de antibióticos no cultivo in vitro da batata em meios semisólido e líquido. Pesquisa Agropecuária Brasileira, v. 38, n. 11, p. 1273-1279, 2003 b.

PEREIRA, J. E. S.; FORTES, G. R. L. Produção de mudas pré-básicas de batata por estaquia a partir de plantas micropropagadas. Horticultura Brasileira, v. 22, n. 2, p. 185-191, 2004a. https://doi.org/10.1590/S010205362004000200005

PEREIRA, J. E. S.; FORTES, G. R. L. Organogênese de ápices meristemáticos de batata em meios de isolamento e multiplicação in vitro. Horticultura Brasileira, v. 22, n. 2, p. 197-201, 2004b.

https://doi.org/10.1590/S0102-05362004000200007

PEREIRA, J. E. S.; MATTOS, M. L. T.; FORTES, G. R. Identificação e controle com antibióticos de bactérias endofíticas contaminantes em explantes de batata micropropagados. Pesquisa Agropecuária Brasileira, v. 38, n. 7, p. 827-834, 2003. https://doi.org/10.1590/S0100-204X2003000700006

PERL, A.; AVIV, D.; GALUN, E. Ethylene and in vitro culture of potato: suppression of ethylene generation vastly improves protoplast yield, plating efficiency and transient expression of an alien gene. Plant Cell Reports, v. 7, n. 6, p. 403-406, 1988.

PONDS, S.; CAMERON, H. Artificial seeds. In: THOMAS, B.; MURPHY, D. J.; MURRAY, B. G. (Eds). Encyclopedia of applied plant sciences. Elseveir, 2003. v. 3, p. 1379-1388. https://doi.org/10.1016/B0-12227050-9/00217-9

PRETOVA, A.; DEDICOVA, B. Somatic embryogenesis in Solanum tuberosum L. cv. Desiree from unripe zygotic embryos. Journal of Plant Physiology, v. 139, p. 539-542, 1992. https://doi.org/10.1016/S01761617(11)80366-4

PROTACIO, C. M.; FLORES, H. E. The role of polyamines in potato tuber formation. In Vitro Cellular \& Developmental Biology - Plant, v. 28, n. 2, p. 81-86, 1992. https://doi.org/10.1007/BF02823023 
PRUSKI, K.; ASTATKIE, T.; NOWAK, J. Jasmonate effects on in vitro tuberization and tuber bulking in two potato cultivars (Solanum tuberosum L.) under different media and photoperiod conditions. In Vitro Cellular and Developmental Biology Plant, v. 38, p. 203-209, 2002. https://doi.org/10.1079/IVPIVP2001265

RAHMAN, Z.; ISLAM, S. M. S.; CHOWDHURY, A. N.; SUBRAMANIAM, S. Efficient microtuber production of potato in modified nutrient spray bioreactor system. Scientia Horticulturae, v. 192, p. 369-374, 2015. https://doi.org/10.1016/j.scienta.2015.06.014

RAVNIKAR, M.; GOGALA, N. Regulation of potato meristem development by jasmonic acid in vitro. Journal of Plant Growth Regulators, v. 9, p. 233-236, 1990. https://doi.org/10.1007/BF02041968

RAVNIKAR, M.; VILHAR, B.; GOGALA, N. Stimulatory effects of jasmonic acid on potato node and protoplast culture. Journal of Plant Growth Regulators, v. 57, p. 151-180, 1992.

https://doi.org/10.1007/BF00193840

ROCHA, P. S. G.; OLIVEIRA, R. P.; SCIVITTARO, W. B. New light sources for in vitro potato micropropagation. Bioscience Journal, v. 31, n. 5, p. 1312-1318, 2015. https://doi.org/10.14393/BJv31n5a2015-26601

ROKKA, V. M. Protoplast technology in genome manipulation of potato through somatic cell fusion. In: LI, X.; DONNELLY, D. J.; JENSEN, T. G. (Eds). Somatic genome manipulation. New York: Springer, 2015. p. 217-235. https://doi.org/10.1007/978-1-4939-2389-2_10

ROKKA, V. M.; TAURIAINEN, A.; PIETILÄ, L.; PEHU, E. Interspecific somatic hybrids between wild potato Solanum acaule Bitt. and anther-derived dihaploid potato (Solanum tuberosum L.). Plant Cell Reports, v. 18, n. 1, p. 82-88, 1998. https://doi.org/10.1007/s002990050536

ROSELL, G.; DE-BERTOLDI, F. G.; TIZIO, R.; DE-BERTOLDI, F. G. In vitro mass tuberization as a contribution to potato micropropagation. Potato Research, v. 30, n. 1, p. 111-116, 1987.

https://doi.org/10.1007/BF02357689

ROSTAMI, F.; EHSANPOUR, A. A. The effect of silver thiosulfate (STS) on chlorophyll content and the antioxidant enzymes activity of potato (Solanum tuberosum L.). Journal of Cell and Molecular Research, v. 2, n. 1, p. 29-34, 2010.

SABETI, M.; ZARGHAMI, R.; EBRAHIM, Z. M. Effects of explants and growth regulators on callogenesis and somatic embryogenesis of Agria potato cultivar. International Journal of AgriScience, v. 3, p. 213-221, 2013.

SALEHI, H.; KHOSH-KHUI, M. A simple procedure for disinfection of "baby masquerade" miniature rose explants. Scientia Horticulturae, v. 68, n. 1-4, p. 145-148, 1997. https://doi.org/10.1016/S03044238(96)00978-8

SANTIAGO, G., REINIGER, L. R. S., HANAUER, J. G., LOPES, S. J., DEPRÁ, M. S. Variação somaclonal nos descritores mínimos de tubérculo em batata. Ciência Rural v. 42, n. 2, p. 197-202, 2012.

https://doi.org/10.1590/S0103-84782012000200002

SARKAR, D.; CHAKRABARTI, S. K.; NAIK, P. S. Slow-growth conservation of potato microplants: efficacy of ancymidol for long-term storage in vitro. Euphytica, v. 117, p. 133-142, 2001.

https://doi.org/10.1023/A:1004087422743

SARKAR, D.; KAUSHIK, S. K.; NAIK, P. S. Minimal growth conservation of potato microplants: silver thiosulfate reduces ethylene-induced growth abnormalities during prolonged storage in vitro. Plant Cell Reports, v. 18, n. 11, p. 897-903, 1999. https://doi.org/10.1007/s002990050681 
SARKAR, D.; NAIK, P. S. Factors affecting minimal growth conservation of potato microplants in vitro. Euphytica, v. 102, n. 2, p. 275-280, 1998. https://doi.org/10.1023/A:1018309300121

SARKAR, D.; PANDEY, S. K.; SHARMA, S. Cytokinins antagonize the jasmonates action on the regulation of potato (Solanum tuberosum L.) tuber formation in vitro. Plant Cell, Tissue and Organ Culture, v. 87, p. 285-295, 2006. https://doi.org/10.1007/s11240-006-9166-3

SCHAFER-MENUHR, A.; MIX-WAGNER, G.; VORLOP, K. D. Regeneration of plants from cell suspension cultures and encapsulated cell suspension cultures of Solanum tuberosum L. Clarissa. Landbauforsch Volk, v. 53, p. 53-59, 2003.

SCHERWINSKI-PEREIRA, J. E. Contaminações microbianas na cultura de células, tecidos e órgãos de plantas. Brasília: Embrapa Informação Tecnológica, 2010. v. 1. 8p.

SEABROOK, J. E. A.; DOUGLASS, L. K. Somatic embryogenesis on various potato tissues from a range of genotypes and ploidy levels. Plant Cell Reports, v. 20, n. 3, p. 175-182, 2001.

https://doi.org/10.1007/s002990000305

SEABROOK, J. E. A.; DOUGLASS, L. K.; TAI, G. C. C. Segregation for somatic embryogenesis on stem internode explants from potato seedlings. Plant Cell, Tissue and Organ Culture, v. 65, p. 69-73, 2001. https://doi.org/10.1023/A:1010632121996

SHAHZAD, A.; SHARMA, S.; PARVEEN, S.; SAEED, T.; SHAHEEN, A.; AKHTAR, R.; YADAV, V.; UPADHYAY, A.; AHMAD, Z. Historical perspective and basic principles of plant tissue culture. In: ABDIN, M.; KIRAN, U.; KAMALUDDIN, A. A. (Eds). Plant Biotechnology: principles and applications. Singapore: Springer, 2017. p.1-36.SHARMA, S. K.; BRYAN, G. J.; WINFIELD, M. O.; MILLAM, S. Stability of potato (Solanum tuberosum L.) plants regenerated via somatic embryos, axillary bud proliferated shoots, microtubers and true potato seeds: a comparative phenotypic, cytogenetic and molecular assessment. Planta, v. 226, p. 1449-1458, 2007. https://doi.org/10.1007/978-981-10-2961-5_1

SHARMA, S. K.; MILLAM, S. Somatic embryogenesis in Solanum tuberosum L.: a histological examination of key developmental stages. Plant Cell Reports, v. 23, n. 3, p. 115-119, 2004. SHARMA, S. K.; MILLAM, S.; HEIN, I.; BRYAN, G. J. Cloning and molecular characterization of a potato SERK gene transcriptionally induced during initiation of somatic embryogenesis. Planta, v. 228, n. 2, p. 319-330, 2008a.

https://doi.org/10.1007/s00425-008-0739-8

SHARMA, S. K.; MILLAM, S.; HEDLEY, P. E.; McNICOL, J.; BRYAN, G. J. Molecular regulation of somatic embryogenesis in potato: an auxin led perspective. Plant Molecular Biology, v.68, n.1, p.185-201, 2008b. https://doi.org/10.1007/s11103-008-9360-2

SHARMA, S.; SARKAR, D.; PANDEY, S. K. Phenotypic characterization and nuclear microsatellite analysis reveal genomic changes and rearrangements underlying androgenesis in tetraploid potatoes (Solanum tuberosum L.). Euphytica, v. 171, p. 313-326, 2010. https://doi.org/10.1007/s10681-009-9983-7

SHI, Y. Z.; CHEN, Q.; LI, H. Y.; BEASLEY, D.; LYNCH, D. R. Somatic hybridization between Solanum tuberosum and S. cardiophyllum. Canadian Journal of Plant Science, v. 86, n. 2, p. 539-545, 2006. https://doi.org/10.4141/P05-076

SHIN, K.; CHO, W.; JEON, E.; JEONG, H.; SEOL, E.; PARK, J.; LEE, Y. Pretreatment method for directly seeding in vitro microtuber. United States Patent: US 2018/0092317 A1, 2018.

SHUKLA, M. R.; SINGH, A. S.; PIUNNO K.; SAXENA, P. K.; JONES, A. M. P. Application of 3D printing to prototype and develop novel plant tissue culture systems. Plant Methods, v. 13, n. 6, p. 1-10, 2017. https://doi.org/10.1186/s13007-017-0156-8 
SILVA, E. C.; PINTO, C. A.; SOUZA-DIAS, J. A. C.; ARAÚJO, T. H. Uso de reguladores de crescimento em brotos destacados de batata-semente. Horticultura Brasileira, v. 29, n. 4, p. 504-509, 2011.

https://doi.org/10.1590/S0102-05362011000400010

SILVA FILHO, J. B.; FONTES, P. C. R.; CECON, P. R.; MCGIFFEN JR, M. E. Evaluation of "UFV Aeroponic System" to produce basic potato seed minitubers. American Journal of Potato Research, [Online], 2018.

SNYDER, G. W.; BELKNAP, W. R. A modified method for routine Agrobacterium-mediated transformation of in vitro grown potato microtubers. Plant Cell Reports, v. 12, n. 6, p. 324-327, 1993. https://doi.org/10.1007/BF00237428

TORRES, A. C.; TEIXEIRA, S. P.; POZZER, L. Cultura de ápices caulinares e recuperação de plantas livres de vírus. In: TORRES, A. C.; CALDAS, L. S.; BUSO, J. A. (Eds). Cultura de tecidos e transformação genética de plantas. Brasília: Embrapa-SPI, 1998. v. 1, p. 133-145.

TOVAR, P.; ESTRADA, R.; SCHILDERENTSCHLER, L.; DODDS, J. H. Inducción y utilización de tubérculos in vitro de papa. Lima: Circular Centro Internacional de la Papa, 1985. 4p.

TOWILL, L. E. Survival at ultra-low temperatures of shoot tips from Solanum tuberosum group andigena, phureja, stenotomum, tuberosum, and other tuber-bearing Solanum species. CryoLetters, v. 5, p. 319-326, 1984.

VARGAS, E. T.; GARCIA, E.; OROPEZA, M. Somatic embryogenesis in Solanum tuberosum from cell suspension cultures: histological analysis and extracellular protein patterns. Journal of Plant Physiology, v. 162, p. 449-456, 2005. https://doi.org/10.1016/j.jplph.2004.07.001

VARGAS, T. E.; XENA, N.; VIDAL, M. C.; OROPEZA, M.; GARCIA, E. Genetic stability of Solanum tuberosum L. cv. Desiree plantlets obtained from embryogenic cell suspension cultures. Interciencia, v. 33, p. 213-218, 2008.

VENKATASALAM, E. P.; SOOD, R.; PANDEY, K. K.; THAKUR, V.; SHARMA, A. K.; SINGH, B. P. Development of low cost technology for in vitro mass multiplication of potato (Solanum tuberosum L.). African Journal of Agricultural Research, v. 8, n. 49, p. 6375-6382, 2013. https://doi.org/10.5958/09740112.2015.00069.9

VENKATASALAM, E. P.; SHARMA, S.; PANDEY, K. K.; SHARMA, S.; THAKUR, V.; SOOD, R.; SINGH, B. P. Influence of hermetic and non-hermetic culture rooms on biochemical and in vitro morphological characters of potato cultivars. Indian Journal of Horticulture, v. 72, n. 3, p. 353-358, 2015.

VIRMOND, E. P.; KAWAKAMI, J.; DIAS, J. A. C. S. Produção de minitubérculos de batata semente através do aproveitamento de brotos. Horticultura Brasileira, v. 29, n. 2, p. 2819-2825, 2011.

WANG, P.; HU, C. In vitro mass tuberization and virus free seed-potato production in Taiwan. American Journal of Potato Research, v. 59, n. 1, p. 33-37, 1982. https://doi.org/10.1007/BF02854881

WANG, K.; HE, W.; AI, Y.; HU, J.; XIE, K.; TANG, M.; WANG, Y.; VANDER ZAAG, P. Optimizing seed potato production by aeroponics in China. Philippine Journal of Crop Science, v. 42, n. 1, p. 69-74, 2017. https://doi.org/10.1007/s11540-006-9011-4

WANG, Q.; LIU, Y.; XIE, Y.;YOU, M. Cryotherapy of potato shoot tips for efficient elimination of Potato leafroll virus (PLRV) and Potato virus Y (PVY). Potato Research, v. 49, n. 2, p. 119-129, 2006. 
WESTCOTT, R. Tissue culture storage of potato germplasm. 1. Minimal growth storage. Potato Research, v. 24, n. 3, p. 331-342, 1981a. https://doi.org/10.1007/BF02360370

https://doi.org/10.1007/BF02360371

WESTCOTT, R. Tissue culture storage of potato germplasm. 2. Use of growth retardants. Potato Research, v. 24, n. 3, p. 343-352, 1981b. https://doi.org/10.1007/BF02360370

https://doi.org/10.1007/BF02360371

WITHERS, L. A.; ENGELMANN, F. In vitro conservation of plant genetic resources. In.: ALTMAN, A.; COLWELL, R. R. (Eds). Agricultural biotechnology. New York: Marcel Dekker, 1998. p. 57-88.

YAMAMOTO, S.; RAFIQUE, T.; FUKUI, K.; CASTILLO MARTINEZ, C. R.; NIINO, T. Application of VCryo-plate method to in vitro shoot tips of potato varieties. In: INTERNATIONAL SYMPOSIUM ON PLANT CRYOPRESERVATION, 2., 2013, Fort Collins, Colorado, USA. Anais... Fort Collins, 2013. p. 31.

YOON, J. W.; KIM, H.; KO, H.; HWANG, H.; HONG, E.; CHO, E.; ENGELMANN, F. Cryopreservation of cultivated and wild potato varieties: effect of subculture of mother-plants and of preculture of shoot tips.

CryoLetters, v. 27, p. 211-222, 2006.

ZHANG, Z. J.; ZHOU, W. J.; LI, H. Z.; ZHANG, G. Q.; SUBRAHMANIYAN, K.; YU, J. Q. Effect of jasmonic acid on in vitro explant growth and microtuberization in potato. Biologia Plantarum, v. 50, n. 3, p. 453-456, 2006. https://doi.org/10.1007/s10535-006-0069-2

ZOBAYED, S. M. A.; ARMSTRONG, J.; ARMSTRONG, W. Micropropagation of potato: evaluation of closed, diffusive and forced ventilation on growth and tuberization. Annals of Botany, v. 87, p. 53-59, 2001. https://doi.org/10.1006/anbo.2000.1299 